\title{
SOCIAL ENTREPRENEURSHIP AS A TOOL FOR THE DEVELOPMENT OF NON-GOVERNMENT ORGANIZATION'S ACTIVITIES: A CASE STUDY OF THE ASSOCIATION "ORANZAIS STARS"
}

Inga Bale ${ }^{1}, \mathrm{MBA}$; Anita Auzina ${ }^{2}$, Dr.oec., assoc.prof.

1,2Latvia University of Life Sciences and Technologies, Latvia

\begin{abstract}
In Latvia, de-institutionalization is gradually taking place, which is envisaged in the European Social Development Plan at the level of public policy. In Latvia, the non-governmental sector (NGO) sector is largely dependent on external funding. In addition, competition for external financing is increasing. One of the solutions to reduce the effect of external financing is to engage in economic activity. Social entrepreneurship is becoming increasingly popular in Latvia - a business model that allows economic activities to be carried out without losing the mission, goals and social impact of NGOs. Social entrepreneurship is a way of effectively addressing the concerns of different groups at risk of social exclusion, which can have a positive long-term impact on the development of both the city and society itself. Social entrepreneurship has the potential to solve various social problems, thus facilitating municipal work and reducing municipal budget expenditures. For municipalities, social enterprises are a tool for solving social problems, which allows them to solve social problems in the municipalities by using a trans-regional approach, without taking risks on investments, failure, changes in market demand. The aim of the study is to create scenarios for the development of NGO activities, using the example of Association "Oranzais stars" (Orange Ray). Main research methods used: monographic method, strategic analysis and planning methods - PEST, SWOT, VRIO matrix, scenario method. The main result of the methods applied in the thesis is the development of a suitable and sustainable business model as the society moves towards the implementation of social entrepreneurship.
\end{abstract}

Key words: social entrepreneurship, NGO, de-institutionalization, persons with mental disabilities, communitybased social services.

JEL code: I38, G30

\section{Introduction}

Social entrepreneurship is increasingly being promoted in Latvia. Social entrepreneurship addresses a specific social problem and measures social impact. Social entrepreneurship can be a small, grassroots initiative implemented in the common interest to solve social problems and, over time, employing classic business methods in its economic activity, with a particular emphasis on measurable positive social impact (Social entrepreneurship [s.a.]). Until now, non-governmental organizations (NGOs), acting in the interest of the public and its groups, have played an important role in addressing social issues and are not profit-making.

In Jelgava city, primary education services for children and young people with mental disabilities are provided for only nine years. Consequently, there is a problem and a vital need to provide young people with mental disabilities (hereinafter referred to as MD) between the ages of 15 and 29 with community-based services where they can spend their leisure time, integrate and receive psychosocial help. At the same time, it would provide support in solving the psychosocial problems of these young people, as well as educational and social rehabilitation services for the restoration or improvement of social functioning abilities, thus ensuring the restoration of social status and integration into the society. Establishing a support service for young people with MD aged 15-29 in Jelgava will simultaneously address a number of social issues - employment and education of the target group, provision of social services, as well as support to reduce the risk of social exclusion in families with children and young people with mental disorders. The research aim is to create scenarios for the development of NGO activities, using the example of Oranzais Stars Association. To achieve

\footnotetext{
${ }^{1}$ Inga Bale e-mail:Inga.bale@inbox.Iv

${ }^{2}$ Anita Auzina e-mail:anita.auzina@llu.Iv
} 
the aim the following specific research tasks are set: 1) study theoretical aspects of social entrepreneurship; 2) find out the normative regulation of social entrepreneurship in Latvia; 3) analyse the activities of NGOs (example of "Oranzais stars"), environment and resources, provide strategic and developmental evaluation of activities; 4) develop scenarios for starting a social business by establishing and developing services for persons with severe MD living in Jelgava and Jelgava municipality. Materials and methods: Combined research approach using qualitative approach - document analysis, questionnaire survey, monographic method, strategic analysis and planning methods - PEST, SWOT, VRIO matrix, scenario method. The target group of the survey are legal representatives of children with disabilities. The population consists of 82 persons. Total number of respondents is 30 .

\section{Research results and discussion}

An innovative, interdisciplinary, form of future business - these are some of the most commonly used terms to describe social entrepreneurship. While some predict this to be the business model of the future, some claim that this is a very ancient practice, since similar traits were observed in the work of the medieval guilds, even more so in the Rocdale pioneer movement of 1844 to work together for a common social purpose. In the case of Rocdale pioneers, it was a response to rising poverty among traders who worked in the traditional trade sector but were threatened by the Industrial Revolution (Doherty, 2009). Here are the hallmarks of $21^{\text {st }}$ century social entrepreneurship - responding to the needs of society to which the state is not responding or responding too sluggishly or unsuitably. Social enterprises are thought to have emerged as a reaction to market or public sector problems in providing public services. The emergence of social entrepreneurship has also been driven by increased competition for external funding in the non-governmental sector (Dobele, 2013). This is also confirmed by the current situation in Latvia. The Satversme (Constitution of the Republic of Latvia) stipulates that Latvia is a socially responsible state, but the fact that Latvia is still one of the poorest member states of the European Union indicates that the Latvian state is not able to fulfil the requirements of the Satversme (Latvijas Republikas Satversme, 1922, Dobele, 2013). It is revealed by indicators compiled by the Central Statistical Bureau of Latvia, which characterize poverty and social exclusion in Latvia and the European Union. The informative review indicates that in 2017 Latvia had the sixth highest proportion of people at risk of poverty or social exclusion, i.e., $28.4 \%$ of the population was at risk of poverty or social exclusion, leaving behind Bulgaria, Romania, Greece, Lithuania, Italy. Moreover, in 2018, the most common problem faced by the Latvian population is low income and its unequal distribution, which is the reason why people are at risk of poverty (Nabadzibas risks..., 2019). There is currently no common definition of social entrepreneurship in the European Union. This term is often used to refer to the principles and forms of entrepreneurship that involve starting a business to achieve social and environmental goals (Social entrepreneurship, [s.a.]).

In Latvia, social entrepreneurship is regulated by the Law on Social Enterprises of the Republic of Latvia, which stipulates that "Social enterprise is a limited liability company which has been granted the status of a social enterprise in accordance with the procedure specified in this law which carries out economic activities with a positive social impact" (Sociala uznemuma likums, 2018). According to the Cabinet of Ministers Regulations No. 173 of 01.04.2018 "Regulations on the Groups at Risk of Social Exclusion and the Procedure for Granting, Registration and Supervision of the Status of a Social Enterprise", a number of indicators are determined for the evaluation of a social enterprise. 
Cabinet of Ministers Regulations No. 173 (01.04.2018) "Regulations on the Groups of People at Risk of Social Exclusion and the Procedure for Granting, Registering and Monitoring the Status of a Social Enterprise" defines groups of people at risk of social exclusion that are essential for social entrepreneurship. The Cabinet of Ministers of the Republic of Latvia has issued the following Cabinet Regulations related to the Law on Social Entrepreneurship, which additionally regulate the issues related to the Law: 1) Cabinet Regulation No. 173 of 27 March 2018, Regulations on the Groups at Risk of Social Exclusion and the Procedures for the Granting, Registration and Monitoring of Social Business Status; 2) Cabinet Regulation No. 101 of 20 February 2018, Regulations on the Social Enterprises Commission; 3) Cabinet Regulation No. 197 of 3 April 2018, Regulations on the Conditions of Granting Commercial Aid to Social Enterprises and the Procedures for Granting Aid; 4) Cabinet Regulation No. 467 of 11 August 2015 Operational Program for Growth and Employment implementing measures of 9.1.1. specific objective "Increase labour market integration of disadvantaged unemployed" for 9.1.1.3. 'Support for social entrepreneurship'.

Association "Oranzais stars" is a non-governmental organization whose core business is non-profit making and its specificity is different from that of other forms of business. It is a voluntary association formed for the purpose of achieving the non-profit objective of the articles of association. However, the association has the right to carry out economic activities in order to achieve the goals of the association and use the proceeds only for the purpose stated in the articles of association (Biedribu un nodibinajumu likums, 2003). The organization was founded on 5 October 2009 for an indefinite period of time with the aim of providing support to families with children with disabilities and children with special needs.

Analysing the financial data of the association, it is concluded that the specifics of the organization significantly influence its financial results. Often, the NGO sector in Latvia uses external funding to organize its activities, i.e. donations, municipal grants, project financing etc. Citizens form NGOs and engage in them for a variety of reasons - the desire to improve one area of public life by seeing the opportunity to contribute to what the public sector has to offer in a given area by raising public awareness of a particular area. In the field of social services, NGOs offer a variety of alternative care services, helping those groups who are unable to take care of themselves, improving the quality of life of certain sections of the population, providing psychological and material support etc. (Parskats par NVO..., 2011).

To investigate the internal and external environment of an organization's operations, a SWOT analysis was performed on the significance of the factors, identifying the impact of the factors on the organisation's performance and revenue. "Creating quality community-based social services" stands out as an important opportunity. One of the most important prerequisites for further development is the "development of quality community-based social services". Unfortunately, 'EU funding for social projects and tendering for social services' is of little importance. But the most important threat to the development of the organization is "low solvency of the target group". On the other hand, when evaluating the data obtained from the PEST analysis, it is concluded that political and economic factors have both positive and negative effects on the performance of the organization. The operation of the organization is significantly influenced by national tax policy, binding legislation and regulations, service requirements, the political situation in the social sphere and increased competition for external financing. Strategic Capability Analysis of Association "Oranzais stars" with the VRIO Matrix demonstrates the impact of the organization's internal environment on the organization's performance, indicating that: 1 ) the organisation's long-term competitiveness benefits 
include: professional staff, recognition, and NGO business potential; 2) a similar competitive advantage is: experience, customer-oriented service design and information resources, including extensive networking. Based on the organisation's diverse resources and skills, the organization can build competitive advantage on the basis of superior innovation and customer satisfaction. To do this, the resources available to the organization - the assets, information and knowledge of the organization - must be used. With these resources, the organization can create and implement strategies. The skills, which are the knowledge, abilities and attitudes required for the successful operation of an organization in a particular sector, play a key role in creating a competitive advantage. Collecting data from the analysis of organizational performance, 3 scenarios of organizational development were identified: new product development, social business start-up, niche strategy.

Table 1

\section{Advantages and disadvantages of the development} scenarios of Association "Oranzais stars"

\begin{tabular}{|l|l|l|}
\hline \multicolumn{1}{|c|}{ Strategy } & \multicolumn{1}{|c|}{ Advantages } & \multicolumn{1}{c|}{ Disadvantages } \\
\hline $\begin{array}{l}\text { New service } \\
\text { development strategy }\end{array}$ & $\begin{array}{l}\text { Free market, Cooperation with NGOs, } \\
\text { Cooperation with recognizable persons, } \\
\text { Technical support, Material resources }\end{array}$ & $\begin{array}{l}\text { Competition, Narrower consumer } \\
\text { base, Limited market capacity }\end{array}$ \\
\hline $\begin{array}{l}\text { Change of the form of } \\
\text { activity (starting a } \\
\text { social business) }\end{array}$ & $\begin{array}{l}\text { Solving the social problem (community } \\
\text { based services and employment } \\
\text { promotion), Financial stability, Operational } \\
\text { development }\end{array}$ & $\begin{array}{l}\text { Bureaucratic burden, Need to } \\
\text { attract investors or seed capital, } \\
\text { Lack of knowledge }\end{array}$ \\
\hline Focusing strategy & $\begin{array}{l}\text { Niche Advantage, Loyalty, Company } \\
\text { Recognition }\end{array}$ & $\begin{array}{l}\text { Inflexibility, Strength of } \\
\text { Suppliers, High Cost }\end{array}$ \\
\hline
\end{tabular}

Source: authors' Study, 2020

As a result of the research, it was concluded that Jelgava city lacks community based services (CBS) for children with functional disabilities and their families. The results of the study show that in order for both parents to continue working in paid employment, to be economically active in Latvia, and to promote the integration of these families into society and to ensure their well-being, Jelgava City Council must provide care and employment for the young people with MD who no longer receive education. In Latvia, the number of consumers in the social sphere is increasing. This is evidenced by the fact that in the period from 2010 to 2018 the proportion of students with special needs integrated (including those of special classes) in the total number of students with special needs (\% per school year) has increased 2.65 times. Likewise, the number of persons with disabilities who received the services of an assistant provided by the municipality during the reporting year increased by 3.39 times during the reporting year from 2013 to 2018 (Socialas politikas raditaji, 2019). 


\section{Defining of the target group of Association "Oranzais stars"}

\begin{tabular}{|c|c|c|c|}
\hline No & $\begin{array}{c}\text { Name of the } \\
\text { responsible authority }\end{array}$ & $\begin{array}{l}\text { Number of persons with functional disabilities } \\
\text { living in Jelgava city and Jelgava district }\end{array}$ & $\begin{array}{c}\text { Target group that needs a day } \\
\text { care centre }\end{array}$ \\
\hline 1. & Jelgava Education Board & No data & 30 young people with MD \\
\hline 2. & $\begin{array}{l}\text { Zemgale Planning Region } \\
\text { (DI project) }\end{array}$ & $\begin{array}{l}\text { In Jelgava, out of } 235 \text { children, individual needs } \\
\text { assessment was performed for } 58 \text { children with } \\
\text { functional disorders; of the } 95 \text { children in Jelgava } \\
\text { district, } 58 \text { children were assessed for individual needs }\end{array}$ & $\begin{array}{l}\text { In Jelgava there are } 15 \text { children } \\
\text { with functional disorders, in } \\
\text { Jelgava district - } 20 \text { children with } \\
\text { functional disorders }\end{array}$ \\
\hline 3. & $\begin{array}{l}\text { Jelgava Social Affairs } \\
\text { Board and Jelgava } \\
\text { District Social Service }\end{array}$ & No data & No data \\
\hline 4. & $\begin{array}{l}\text { Medical Commission on } \\
\text { Expertise in Health and } \\
\text { Work Ability }\end{array}$ & $\begin{array}{l}\text { There are } 232 \text { disabled persons aged } 16-29 \text { living in } \\
\text { Jelgava and } 1 \text { disabled person aged 16-29 living in } \\
\text { Jelgava district }\end{array}$ & $\begin{array}{l}\text { In Jelgava and Jelgava district the } \\
\text { total number of persons with MD } \\
\text { aged } 16-29 \text { is } 88 \text { persons }\end{array}$ \\
\hline 5. & $\begin{array}{l}\text { Centre for Disease } \\
\text { Prevention and Control }\end{array}$ & $\begin{array}{l}\text { There are } 104 \text { patients with psychiatric and behavioral } \\
\text { disorders living in Jelgava and } 101 \text { patients with } \\
\text { psychiatric and behavioral disorders diagnosed in Jelgava } \\
\text { district }\end{array}$ & $\begin{array}{l}\text { In Jelgava and Jelgava district the } \\
\text { total number of persons with MD } \\
\text { aged } 16-29 \text { is } 82 \text { persons }\end{array}$ \\
\hline
\end{tabular}

Source: authors' Study, 2020

Based on the above, it is concluded that the data provided by the authorities on the number of persons with MD (16-29 years) varies. The difference in data is assumed to be due to differences in the accounting of the data and to the competence of the authorities providing the information. The assumption is that the target group of the study is 82 persons aged 16-29 living in Jelgava and Jelgava district. A survey was conducted to evaluate the aspects of setting up a day care centre and the views of legal representatives of young people with disabilities. Survey results show that one third of respondents hire a carer or assistant from their family budget. In addition, $90 \%$ of respondents find it very important for a young person to continue receiving an education or day care centre after leaving primary school, however, $43 \%$ of the surveyed legal representatives say that children's functional disorders make it difficult to pursue further education. Analysing the data on the functional disorders of the children of the respondents, it is concluded that $56.7 \%$ are children with mental disorders, $16.7 \%$ children have physical impairments and $26.6 \%$ - combined functional disorders. The results of the survey show that $86.7 \%$ of respondents' children attend an educational institution and $14.3 \%$ do not attend either an educational institution or a day care centre (DCC). Respondents reveal that they are children over the age of 16 who no longer receive education and also do not attend a DCC, as there is currently no such service in Jelgava and Jelgava district and, accordingly, it is not available to the families.

On the basis of the analysis of the activities of the "Oranzais stars" association, it is concluded that the association is recommended to establish a new company and register its activities in the registers of social enterprises and social service providers, thus increasing access to public funding for both business start-ups and service payments. Developing social entrepreneurship within the association would primarily reduce the high impact of external funding on organizational performance and increase financial stability, while addressing a number of social challenges. Using the problem tree model, the social problem was identified and the relationship between the cause and the various factors affecting it identified. Identifying a problem allows a more reliable explanation of the problem to potential stakeholders. Consequence identification, in turn, allows the cause of the problem to be identified (Enabling inclusive cities..., 2017). Key issue: young people with severe MD do not have access to community-based social services. The root causes: 1) persons with severe functional disabilities need continuous care; 2) successful family functioning requires appropriate services - 
educational and social. Consequences: 1) exposure to poverty risk; 2) unemployment (both young and old); 3) risk of social exclusion; 4) burnout of parents and risk of physical and mental illness.

As a legal entity, the Association may establish a limited liability company (hereinafter "Ltd"), a limited liability company (minimum share capital of 2800 EUR), which must be registered in the Commercial Register in order to start a business (Komerclikums, 2000). The next step is the registration of the newly established Ltd in the social enterprise register to obtain the status of a social enterprise (decision of the shareholders' meeting and decision of the Ministry of Welfare on recognition of the status of a social enterprise). The social business model is based on three main components - beneficiary, measurable social impact and profit. The authors developed 3 development scenarios for care and employment of young people with MD aged 15-29 living in Jelgava.

Development Scenario 1: Social enterprise "Day care centre where the municipality purchases services" - a social service is created - a day care centre for persons with severe MD from the age of 15 . The service is offered by the newly established social enterprise in cooperation with Jelgava municipality.

\section{Advantages and disadvantages of development Scenario 1 "Social enterprise DCC where municipality purchases services"}

\begin{tabular}{|l|l|l|}
\hline No & \multicolumn{1}{|c|}{ Advantages } & \multicolumn{1}{c|}{ Disadvantages } \\
\hline $\mathbf{1 .}$ & $\begin{array}{l}\text { Social security. Creating a } \\
\text { system to make society feel } \\
\text { good while living in its } \\
\text { territory. }\end{array}$ & $\begin{array}{l}\text { There is a possibility that in the future the municipality may not financially support } \\
\text { the establishment of DCC, besides there is a high risk that the municipality may } \\
\text { prioritizing another social problem and shifting funding to other activities or } \\
\text { purchasing the service from another service provider. }\end{array}$ \\
\hline $\mathbf{2 .}$ & $\begin{array}{l}\text { The municipality co-finances } \\
\text { the maintenance of the } \\
\text { centre. }\end{array}$ & $\begin{array}{l}\text { The company makes no profit and does not perform the function of a social } \\
\text { enterprise by its very nature. }\end{array}$ \\
\hline $\mathbf{3 .}$ & $\begin{array}{l}\text { Families of the customers co- } \\
\text { finance the cost of the } \\
\text { service, thereby assuring } \\
\text { their co-responsibility. }\end{array}$ & $\begin{array}{l}\text { The municipality believes that due to lack of resources, the service should be set up } \\
\text { by an NGO or a social enterprise, attracting Central Finance and Contracting Agency } \\
\text { (CFCA) funding or other grants. }\end{array}$ \\
\hline $\mathbf{4 .}$ & - & $\begin{array}{l}\text { According to R.Sturane, head of Jelgava Social Affairs Department, on 18 February } \\
\text { 2020, Jelgava City Municipality faces the challenge of achieving performance } \\
\text { indicators and providing the necessary services, including for children with functional } \\
\text { disabilities. It is known that a part of the deinstitutionalization project social services } \\
\text { will be launched around February 2023. }\end{array}$ \\
\hline $\mathbf{5 .}$ & - & $\begin{array}{l}\text { The municipality must organize the procurement for the provision of the service. It is } \\
\text { possible to reduce the price of the service or to change the service provider. }\end{array}$ \\
\hline $\mathbf{6 .}$ & - & $\begin{array}{l}\text { Reconstruction of Lielplatone Primary School-Support Centre in Jelgava District with } \\
\text { the aim of developing DCC for children and young people with functional disorders. }\end{array}$ \\
\hline $\mathbf{5 o u r}$
\end{tabular}

Source: authors' Study, 2020

The main tasks for the implementation of the 1st development scenario are the agreement with Jelgava municipality on the establishment of the centre and the services provided by the company, while mutually agreeing on the resources. At the same time, it is necessary to attract external funding for the centre (crowd funding, donations, endowments, ALTUM grants, projects, business angels etc.). The process of establishing the DCC should include promoting the business idea and informing the public, as well as reaching out to the target group and contracting with legal representatives. Finally, staff selection and training will be carried out.

Development Scenario 2 "Youth Farm" - social service is created - DCC for persons with severe MD ages 15 and over - "Youth Farm". The service is offered by a newly created social enterprise. Clients are cared for and employed, and the results of operations are used to maintain the centre. 
Advantages and disadvantages of development Scenario 2 "Youth Farm"

\begin{tabular}{|c|c|c|}
\hline No & Advantages & Disadvantages \\
\hline 1. & $\begin{array}{l}\text { Creating a customer-oriented social service (individually } \\
\text { designed service program). A complex of services and } \\
\text { continuity of services are provided. }\end{array}$ & $\begin{array}{l}\text { It is necessary to attract external financing or } \\
\text { investment for the DCC infrastructure. }\end{array}$ \\
\hline 2. & $\begin{array}{l}\text { Promoting employment for social risk groups through } \\
\text { competitive pay. Economic activity and alternative jobs } \\
\text { are increasing. }\end{array}$ & $\begin{array}{l}\text { Expenditure over revenue, high administrative costs. } \\
\text { High financial risk. The dependence on external financing } \\
\text { is not sufficiently reduced and additional external } \\
\text { financing needs to be attracted. }\end{array}$ \\
\hline 3. & Possibility to use infrastructure to create new services. & $\begin{array}{l}\text { Municipal resources may be required to provide a quality } \\
\text { service that meets customer needs. }\end{array}$ \\
\hline 4. & $\begin{array}{l}\text { Social entrepreneurs have preferential procurement } \\
\text { contracts. }\end{array}$ & $\begin{array}{l}\text { For a social entrepreneur, the outcome is not always } \\
\text { important, but the process is important. }\end{array}$ \\
\hline 5. & $\begin{array}{l}\text { Business methods address a social problem. It is not a } \\
\text { priority to generate a dividend payout to the owners. }\end{array}$ & $\begin{array}{l}\text { Low solvency of the target group (concerns family co- } \\
\text { financing). }\end{array}$ \\
\hline 6. & - & $\begin{array}{l}\text { There is a lack of real municipal and state support } \\
\text { mechanisms for long-term social entrepreneurship. }\end{array}$ \\
\hline 7. & - & DCC services are semi-seasonal in nature. \\
\hline
\end{tabular}

Source: authors' Study, 2020

The main tasks for the implementation of development scenario $\mathbf{2}$ "Youth Farm" are to attract external financing for the centre (crowd funding, donations, endowments, ALTUM grants, projects, business angels etc.), followed by the purchase of the building and adjacent area; improvement, creation of centre and sensory room, arrangement, as well as creation of material and technical basis. After the establishment of the centre, similarly to development scenario 1 , it is necessary to promote the business idea and inform the public, address the target group, as well as carry out personnel selection and training. Additional tasks for scenario development include planning of agricultural events with the involvement of agricultural experts, assessment of customer abilities, planning of service volume and marketing activities for marketing of goods.

Development Scenario 3 "DCC in municipal delegation": a social service is created - DCC for persons with severe MD aged 15 and over. The municipality establishes the centre with its own infrastructure and concludes a delegation agreement with the newly created company, which operates accordingly to provide the services needed by the centre's clients. Clients are employed through cooperation with other entrepreneurs. After analysing the survey data, information provided by experts, data compiled by the author, and the advantages, disadvantages, and revenue and expenditure projections of each society development scenario, author concludes that Scenario 3 "DCC in municipal delegation" is best suited for a social enterprise to realize a business idea. 
Advantages and disadvantages of development Scenario 3 "DCC in municipal delegation"

\begin{tabular}{|c|c|c|}
\hline No & Advantages & Disadvantages \\
\hline 1. & Social enterprise is a tool for a municipality to solve a social problem. & $\begin{array}{l}\text { Municipal action must always have a } \\
\text { legal basis. }\end{array}$ \\
\hline 2. & $\begin{array}{l}\text { The municipality does not have to organize the procurement, in a sense } \\
\text { creating security for the social enterprise. }\end{array}$ & $\begin{array}{l}\text { To achieve the optimum result, you } \\
\text { have to balance the equilibrium price } \\
\text { with the real price. }\end{array}$ \\
\hline 3. & $\begin{array}{l}\text { Under the Local Government and Social Assistance Act, the Municipality } \\
\text { must provide DCC service to persons with MD. }\end{array}$ & $\begin{array}{l}\text { Difficulties in attracting companies for } \\
\text { which young people with MD could do } \\
\text { some work. }\end{array}$ \\
\hline 4. & $\begin{array}{l}\text { Ready infrastructure, no need to invest your own resources in building the } \\
\text { infrastructure. }\end{array}$ & - \\
\hline 5. & Discretion in the exercise of an economic activity. & - \\
\hline 6. & $\begin{array}{l}\text { A social enterprise can use municipal resources and available methods as } \\
\text { one of its operating methods. }\end{array}$ & - \\
\hline 7. & $\begin{array}{l}\text { Social enterprise is not restricted. The municipality has restrictions (money, } \\
\text { tools, volume, territory), the social enterprise does not. }\end{array}$ & - \\
\hline 8. & $\begin{array}{l}\text { The municipality can use "other" methods to solve the social problem. Use } \\
\text { methods that are not typical for municipalities, a trans-regional approach, } \\
\text { not to take risks on investment, failure, changes in market demand. }\end{array}$ & \\
\hline 9. & $\begin{array}{l}\text { Understanding of the legal environment. It is not always necessary to } \\
\text { create an authority, institution or municipal authority for every problem. }\end{array}$ & - \\
\hline
\end{tabular}
Source: authors' Study, 2020

In order to develop Scenario 3 "DCC in municipal delegation", it is necessary to agree with Jelgava City Municipality on the provision of DCC services in the infrastructure created by the municipality by concluding a delegation agreement. This is followed by addressing the target group, contracting with legal representatives, evaluating customer capabilities, planning the scope of services and selecting and training the appropriate staff accordingly. The development of economic activity requires marketing activities to popularize services and attract partners.

Table 6

Summary of scenarios for setting up a day care centre in Jelgava

\begin{tabular}{|c|c|c|c|c|}
\hline Scenarios & Identified problems & Solutions & $\begin{array}{l}\text { Estimated } \\
\text { annual } \\
\text { expenditure, } \\
\text { thsd. Euro } \\
\end{array}$ & $\begin{array}{l}\text { Estimated } \\
\text { annual } \\
\text { revenue, } \\
\text { thsd. Euro }\end{array}$ \\
\hline $\begin{array}{l}\text { Scenario } 1 \text { "Social } \\
\text { enterprise DCC } \\
\text { where } \\
\text { municipality } \\
\text { purchases } \\
\text { service" }\end{array}$ & $\begin{array}{l}\text { Jelgava lacks CBS for young } \\
\text { people with severe MD, } \\
\text { resulting in difficulties for } \\
\text { legal representatives of young } \\
\text { people with severe MD to } \\
\text { enter the open labour market }\end{array}$ & $\begin{array}{l}\text { Establishment of a DCC centre } \\
\text { for young people with severe } \\
\text { MD, where care is provided. }\end{array}$ & 151.8 & 183.6 \\
\hline $\begin{array}{l}\text { Scenario } 2 \text { "Youth } \\
\text { Farm" }\end{array}$ & $\begin{array}{l}\text { Jelgava lacks CBS for young } \\
\text { people with severe MD, } \\
\text { resulting in difficulties for } \\
\text { legal representatives of young } \\
\text { people with severe MD to } \\
\text { enter the open labour market }\end{array}$ & $\begin{array}{l}\text { Establishment of a DCC centre } \\
\text { for young people with severe } \\
\text { MD, providing care, leisure, } \\
\text { education, employment and } \\
\text { employment of legal } \\
\text { representatives of young } \\
\text { people. }\end{array}$ & 218.4 & 120.0 \\
\hline $\begin{array}{l}\text { Scenario } 3 \text { "DCC } \\
\text { in municipal } \\
\text { delegation" }\end{array}$ & $\begin{array}{l}\text { Jelgava lacks CBS for young } \\
\text { people with severe MD, } \\
\text { resulting in difficulties for } \\
\text { legal representatives of young } \\
\text { people with severe MD to } \\
\text { enter the open labour market }\end{array}$ & $\begin{array}{l}\text { Establishment of a DCC center } \\
\text { for young people with severe } \\
\text { MD, providing care, leisure, } \\
\text { education, employment and } \\
\text { employment of legal } \\
\text { representatives of young } \\
\text { people. }\end{array}$ & 218.4 & 216.0 \\
\hline
\end{tabular}

Source: authors' Study, 2020

After analysing all the developed scenarios, it is concluded that Scenario 3 "DCC in municipal delegation" is the most suitable for implementing the social enterprise business idea. This business model is focused on solving the social problem facing children in Jelgava and its immediate vicinity, 
and the business idea has great potential for social impact and expansion, as well as the possibility to become financially self-sufficient in the future.

\section{Conclusions, proposals, recommendations}

1) Social entrepreneurship is a way to solve effectively the problems of people at different risks of social exclusion, which can have a positive impact on the development of the city and society in the long run. By implementing the social entrepreneurship, it is possible to facilitate the work of the municipality and reduce the municipal budget expenses.

2) Association "Oranzais stars" has the necessary resources and platforms for successful social entrepreneurship and new community-based social services. However, the "Low solvency of the target group" is a significant threat to the development of the association. It may hinder development in the long run.

3) Children and young people with mental disabilities in the city of Jelgava have only basic education services, thus there is a problem and a significant need to provide young people with mental disabilities between the ages of 15 and 29 with a place to spend their free time, integrate into society and receive psychosocial assistance. Also, the research results reflect the topicality of this problem. Community-based services for young people with mental disabilities would contribute the integration of families into society and ensure their well-being, as well as reduce the risk of social exclusion.

4) In order for families with children with mental disabilities to function successfully, they need to receive appropriate services - educational and social. If such services are not available, there is a risk that these families will be exposed to poverty, unemployment (both young and old), social exclusion, parental burnout and exposure to physical and mental illness.

5) After evaluating the development scenarios of the Association "Oranzais stars", Scenario No. 3 "Day care centre in the delegation of the municipality" is the most effective that provides development of the new community-based services. The developed development scenario has a great potential for social impact and expansion and in the long run it is a financially self-sufficient.

\section{Bibliography}

1. Dobele, L. (2013). Socialas uznemejdarbibas attistibas iespejas Latvija (Social business development opportunities in Latvia): promocijas darbs (doctoral thesis). Latvijas Lauksaimniecibas universitate (Latvia University of Life Sciences and Technologies). Ekonomikas un sabiedribas attistibas fakultate (Faculty of Economics and Social Development). Jelgava: LLU. 218 Ipp.

2. Doherty, B., Foster, G., Mason, C., Meehan, J., Meehan, K., Rotheroe, N., Royce M. (2009). Management for Social Enterprise. London: SAGE publications, pp. 1-54.

3. Enabling inclusive cities: tool hit for inclusive urban development (2017) Mandaluyong City, Philippines. Asian development bank.

4. Komerclikums (Commercial law) (2002). LR Likums (Law of the Republic of Latvia). Retrieved: https://likumi.Iv/ta/id/5490-komerclikums. Access 09.03.2020.

5. Latvijas Republikas Satversme (The Constitution of the Republic of Latvia) (1922): LR Likums (Law of the Republic of Latvia) Retrieved: https://likumi.lv/ta/id/57980-latvijas-republikas-satversme. Access: 06.01.2020.

6. Likums "Biedribu un nodibinajumu likums" (Law on Associations and Foundations) (2003): LR likums (Law of the Republic of Latvia).Retrieved: https://likumi.Iv/doc.php?id=81050. Access 17.10.2019.

7. Nabadzïbas risks un sociala atstumtiba Latvija (Risk of poverty and social exclusion Latvia). Informativs apskats (Informative review). Centrala statistikas parvalde (Central Statistical Bureau), Retrieved: https://www.csb.gov.Iv/sites/default/files/publication/2019-01/Nr_8-

2_Nabadzibas_risks_un_sociala_atstumtiba_Latvija_2018_\%2819_00\%29\%20LV.pdf.Access 14.01.2020

8. Noteikumi par socialas atstumtibas riskam paklauto iedzivotaju grupam un sociala uznemuma statusa pieskirsanas, registresanas un uzraudzibas kartibu (Regulations on the Procedure for Granting, Registeringand Monitoring the Status of the Population at Risk of Social Exclusion and the Status of a Social Enterprise ) (2018), MK not. nr.173. (Regulations of the Cabinet of Ministers No 173) Retrieved: 
https://likumi.Iv/ta/id/298035-noteikumi-par-socialas-atstumtibas-riskam-paklauto-iedzivotaju-grupam-unsociala-uznemuma-statusa-pieskirsanas-registresanas. Access 06.03.2020.

9. Parskats par NVO sektoru Latvija (Overview of the NGO sector in Latvia )(2011). Sabiedrības integracijas fonds (Society Integration Rund), http://www.biss.soc.Iv/downloads/resources/SIF_Parskats_par_NVO_sektoru_Latvija.pdf. Access 16.10 .2019

10. Sociala uznemejdarbiba (Social entrepreneurship) [without the year] LR Labklajibas Ministrija, Retrieved: http://www.Im.gov.Iv/lv/index.php?option=com_content\&view=article\&id=80690. Access 06.01.2020

11. Sociala uznemuma likums (Social enterprise law )(2018): LR Likums (Law of the Republic of Latvia). Retrieved: https://likumi.lv/ta/id/294484-sociala-uznemuma-likums. Access:06.01.2020.

12. Socialas politikas raditaji (Social policy indicators). LR Labklajības ministrija (Ministry of Welfare of the Republic of Latvia). Retrieved: http://www.Im.gov.Iv/Iv/publikacijas-petijumi-un-statistika/statistika. Access 06.12.2019. 